\title{
A survey study on ashtoum El-Gamil park's water concerning phytoplankton populations
}

\author{
Mohamed S. Abd El-Karim ${ }^{1}$, Abdelhamid M. Abdelhamid ${ }^{2}$, Manal I. El- \\ Barbary $^{3}$ and Eldeweny M. E. Mabrouk ${ }^{2}$
}

1- Hydrobiology Lab., National Institute of Oceanography and Fisheries, Cairo, Egypt;

2- Dept. of Animal Production, Faculty of Agriculture, Mansoura University, Egypt; and 3- Dept. of Fish Pathology, National Institute for Oceanography and Fisheries, Cairo, Egypt.

\section{ABSTRACT}

Among the 19 water samples collected year round during $(2010$ - 2011) from Ashtoum El-Gamil Park, 12 samples succeeded to cluster above similarity level of $60 \%$. The samples of similarity less than $60 \%$ were mainly sampled during summer. Total phytoplankton diversity marginally changed between lake stations. The highest diversity of 3.1 was found at station No. 4 in winter where a minimum diversity of 1.14 was found at station No. 1 in spring. The dominant classes in Lake Manzala (Ashtoum El-Gamil Park) were chlorophytes, diatoms and cyanoprokaryotes. The three groups altogether constitute more than $95 \%$ and $85 \%$ of the total phytoplankton abundance and total number of taxa, respectively. Based on cell number, the chlorophytes ranked the first position of dominance with relative abundance of $84.23 \%$ and they exclusively dominated the phytoplankton communities year round. Regarding the species composition, chlorophytes dominated the phytoplankton species composition with percentage occurrence of $44 \%$ to the total number of recorded species. The phytoplankton abundance showed major peaks during spring at different stations except at station No. 2 where the highest abundance of 28716 cells $\mathrm{x}$ $10^{5} 1^{-1}$ was found, whereas the minor peaks were irregularly distributed between other seasons with the least abundance of 704 cells $\times 10^{5} 1^{-1}$ which was detected during winter at station No. 4. Generall, the total number of taxa per site showed no obvious pattern of variation. It is concluded that presence and biodiversity of phytoplankton are affected by locations and seasons, and the pollution is under the critical levels.

Keywords: Chlorophyceae - Cyanophyceae - Bacillariophyceae - Dinophyceae - EuglenophyceaeCryptophyceae - Prasinophyceae - Ashtoum El-Gamil.

\section{INTRODUCTION}

Coastal lagoons are unique systems, typically characterized by bidirectional horizontal flows, permanent mixing of the water column, and abrupt changes in residence time. In these systems, continues fresh highly enriched water and marine intrusions cause large temporal and spatial variations in phytoplankton composition, production and functional groups (Billina et al., 2005). Manzala Lagoon is a typical coastalanean seawater via three points, El-Gamil, El-Boughdady and New El-Gamil, which has been recently established (Fayed, 2004), and secondly, fresh-highly enriched water from several drains and pumping stations. Together, saline-less productive seawater and fresh highly nutrient loaded drainage water formed a local variation in trophy, salinity and electrical conductivity. Phytoplankton is known to react sensitively to differences in catchment-derived chemical characteristics (Rosen, 1981 and Arvola et al., 1999). Indicator species for different nutritional levels have been presented for oligotrophic waters (Brettum, 1989). Willen (2000) pointed out that knowledge of the structure (taxa, abundances and biomass) and function 
(response to the environmental conditions) of phytoplankton is important when assessing the links between phytoplankton and the environment. The taxonomic composition and abundance of phytoplankton is one of the biological metrics in the normative definitions of ecological status classification in the Water Framework Directive (European Union, 2000). The phytoplankton communities in Lake Manzala underwent changes from diatoms-dominated communities to non-diatoms-dominated communities. The early available studies of the phytoplankton (Maclaren, 1981 and Khalil, 1990) indicated that the phytoplankton communities were, numerically, diatoms-dominated, while cyanobacteria and chlorophytes were subdominant. In mid 1990s, El-Sherif and Gharib (2001) reported a transient stage with dominance of diatoms through winter and spring, while chlorophytes and cyanobacteria dominated through autumn and summer, respectively. More recently, Sobhy (2007) postulated that Cyanobacteria dominated the phytoplankton communities (relative abundance of 48.468\%), Chlorophyceae (relative abundance of 29.204\%), whereas Bacillariophyceae became subdominant (relative abundance of 20.7\%). However, the ongoing study aimed to survey the present status of the phytoplankton population in Ashtoum El-Gamil Park' water to throw light on the environmental pollution in this water body.

\section{MATERIALS AND METHODS}

\section{Sampling Locations:}

Lake Manzalah is the largest of the Nile Delta lakes. It is located in the northeastern part of Egypt. It is bounded on the east by the Suez Canal and on the west by Damietta branch of the Nile and is separated from the Mediterranean Sea by a narrow sandy fringe at the north. The lake is connected to the Mediterranean Sea through a narrow channel (Boughaz El-Gamil). The islands and reed beds divide the lake into well defined basins each is known as Bahr having more or less distinctive ecological conditions (Abdel-Baky et al., 1991). Samples were collected during the four seasons (2010-2011) from five stations, being: station 1: inlet of El-Gamil old in the north-east, station 2: inlet of El-Gamil new in the north-west, station 3: bahr Kassab near to the middle, station 4: bahr Bashtier in the south-west and station 5: bahr Kur in the south-east.

\section{Collection of water samples:}

Water samples were collected (seventy five samples for each season, fifteen samples/location/season). The water samples were collected in clean 1 liter polyethylene bottles from a depth of $50 \mathrm{~cm}$ of the sampling locations. Phytoplankton samples were fixed with $4 \%$ formaline solution enumerated and counted using the inverted microscope method (Utermohl, 1958). Identification of the main phytoplanktonic groups was made with reference of: Cyanobacteria (Starmach, 1968) Bacillariophyceae (Krammer and Lange-Bertalot, 1986) and Chlorococcales (Dillard, 1989, 1990 and 1991) and (Tikkanen, 1986).

\section{RESULTS}

\section{Classification of Samples:}

Among the 19 collected samples year round, 12 samples succeeded to cluster above similarity level of $60 \%$ (Fig. 1). The samples of similarity less than $60 \%$ were mainly sampled during summer. The resulted groups were labeled A, B, C and D. Group A composed of four samples collected mainly in summer and one sample 
during winter. The samples of group B were collected mainly during autumn and one sample during summer, whereas group $\mathrm{C}$ composed of five samples and collected mainly during spring and one sample in autumn. Group D composed of three samples collected in winter and spring.

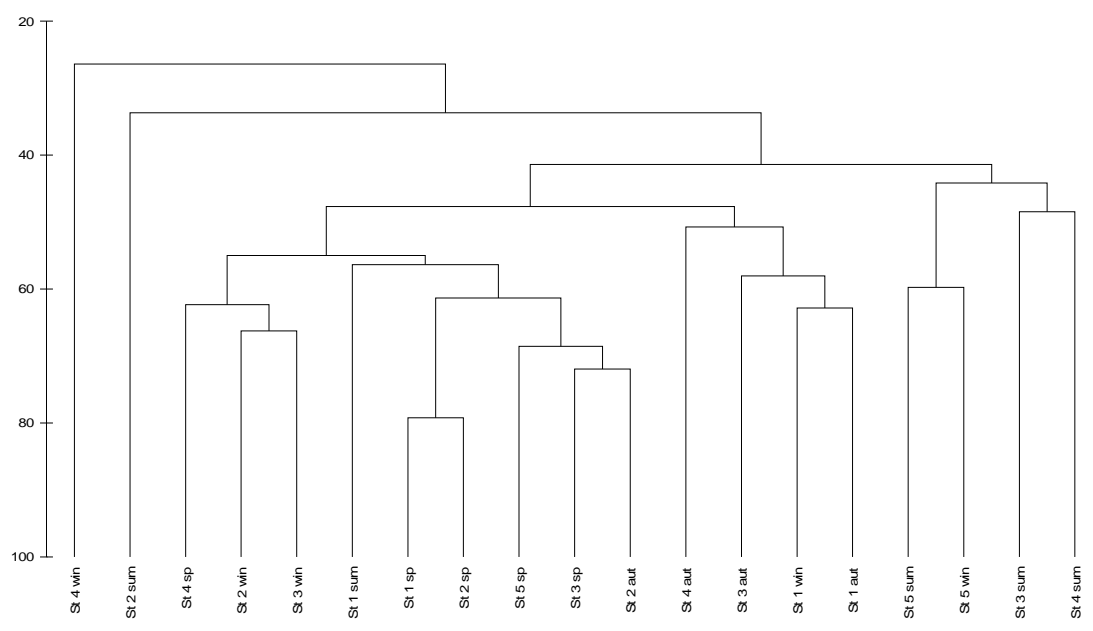

Fig. 1: Similarity matrix between sampling stations

\section{Evenness and Diversity:}

Completely even distribution (each species has the same abundance) gives an evenness index of 1 . Completely dominance of only one species gives an index of 0 . The evenness index shows low equitability for phytoplankton species in Lake Manzala with average value of 0.42 and a maximum of 0.74 at station 4 in winter, whereas a minimum of 2.4 was detected at station No. 2 in autumn. Total phytoplankton diversity marginally changed between lake stations. The highest diversity of 3.1 was found at station No. 4 in winter where a minimum diversity of 1.14 was found at station No. 1 in spring (Fig. 2).

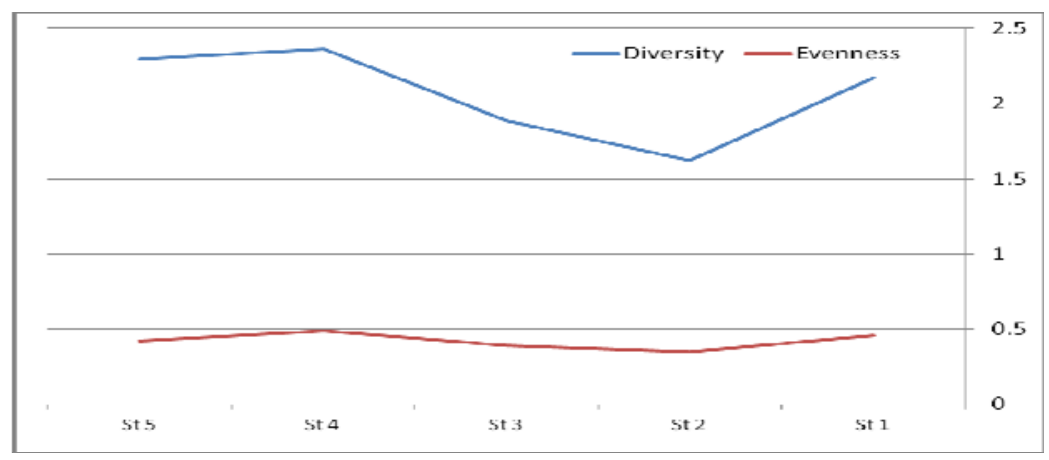

Fig. 2: Distribution of seasonal average of diversity and evenness

\section{Phytoplankton abundance and class composition:}

Community composition:

The dominant classes in Lake Manzala were chlorophytes, diatoms and cyanoprokaryotes. The three groups altogether constitute more than $95 \%$ and $85 \%$ of the total phytoplankton abundance (Fig. 3) and total number of taxa (Fig. 4), respectively. Based on cell number, the chlorophytes ranked the first position of dominance with relative abundance of $84.23 \%$ and they exclusively dominated the 
phytoplankton communities year round. Regarding the species composition, chlorophytes dominated the phytoplankton species composition with percentage occurrence of $44 \%$ to the total number of recorded species. Cyanophytes ranked the second position with 29 species and a percentage of $21 \%$ whereas diatoms ranked the third position of occurrence with total number of 27 species and a percentage of $20 \%$. The other groups were Dinophyceae, Euglenophyceae, Prasinophyceae and Cryptophyceae, these groups were scarcely and sporadic present.

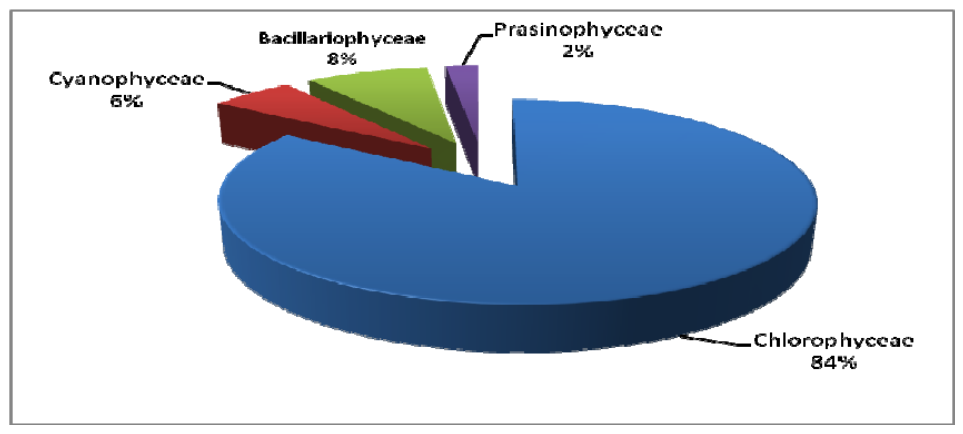

Fig. 3: Percentage abundance of different groups to the total phytoplankton

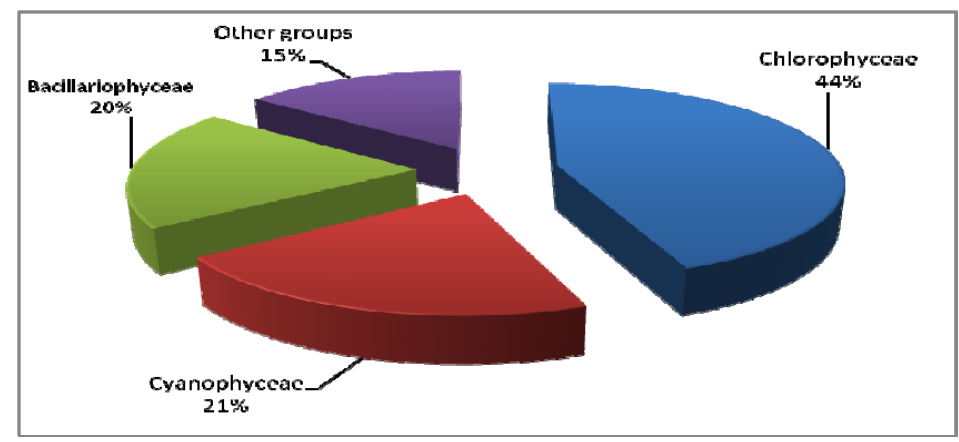

Fig. 4: Percentage occurrence of different groups to the total phytoplankton

\section{Distribution of total phytoplankton:}

The phytoplankton abundance showed major peaks during spring at different stations except at station No. 2 where the highest abundance of 28716 cells $\times 10^{5} 1^{-1}$ was found, whereas the minor peaks were irregularly distributed between other seasons with the least abundance of 704 cells $\times 10^{5} 1^{-1}$ which was detected during winter at station No. 4 (Table 1 and Fig. 5).

Table 1: Seasonal distribution of total phytoplankton (No. of cells x $10^{5} 1^{-1}$ ) during 2010/2011

\begin{tabular}{llllll}
\hline & Spring & Summer & Winter & Autumn & \multicolumn{1}{c}{ Average } \\
\hline St 1 & 12624 & 9414 & 5966 & 5758 & 8440.5 \\
St 2 & 17928 & 1142 & 9412 & 28716 & 14299.5 \\
St 3 & 24944 & 7556 & 9394 & 4840 & 11683.5 \\
St 4 & 14886 & 9565 & 704 & 3182 & 7084.25 \\
St 5 & 24204 & 11911 & 6018 & -- & 14044.333 \\
\hline
\end{tabular}




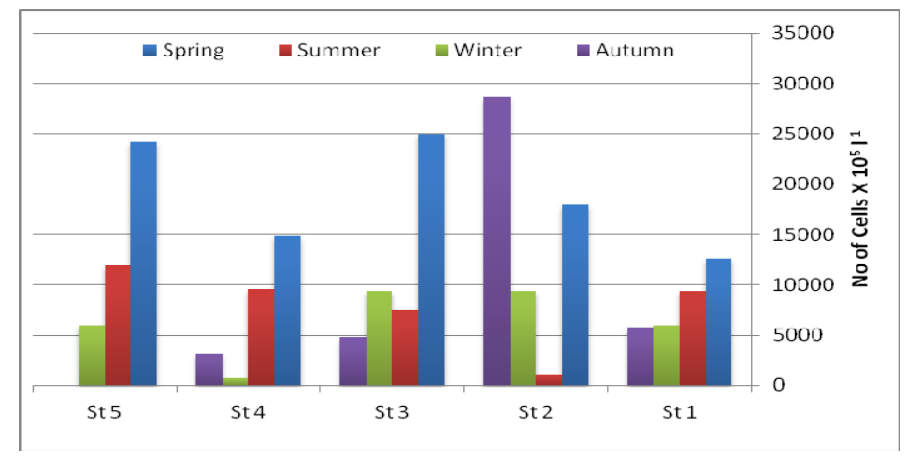

Fig. 5: Seasonal distribution of total phytoplankton

\section{The spatial and temporal distribution of Chlorophyceae:}

Chlorophyceae ranked the first position of dominance with an average abundance of $84 \%$. Chlorophyceae showed a higher development at stations No. 2, 3, and 5 with a small abundance at stations No. 1 and 4. Temporally, the chlorophytes showed highest average abundance ( 17178.8 cells $\left.\times 10^{5} 1^{-1}\right)$ in spring and gradually decreased till reached its minimum abundance during winter $\left(4260\right.$ cells $\left.\times 10^{5} 1^{-1}\right)$ followed by a marginal increase during autumn (Fig. 6).

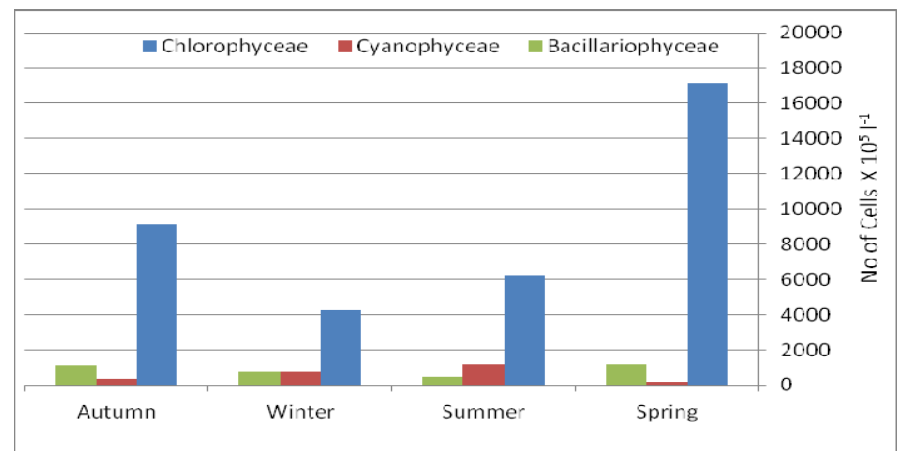

Fig. 6: Average seasonal distribution of different phytoplankton main classes

The chlorophytes percentage abundance was highest in spring and lower in winter. The highest chlorophytes of $98.6 \%$ was recorded at station No. 1 during spring whereas the least of $49.8 \%$ was found at station No. 5 during summer (Table 2).

Table 2: Chlorophyceae distribution in the area of study (No. of cells x $10^{5} 1^{-1}$ )

\begin{tabular}{lllllllllll}
\hline & \multicolumn{2}{c}{ Spring } & \multicolumn{2}{c}{ Summer } & \multicolumn{2}{c}{ Winter } & \multicolumn{2}{c}{ Autumn } & \multicolumn{2}{c}{ Average } \\
& Abund. & $\%$ & Abund. & $\%$ & Abund. & $\%$ & Abund. & $\%$ & Abund. & $\%$ \\
\hline St 1 & 12444 & 98.6 & 9018 & 95.8 & 4380 & 73.4 & 3510 & 61.0 & 7338.0 & 86.9 \\
St 2 & 17544 & 97.9 & 666 & 58.3 & 7352 & 78.1 & 25840 & 90.0 & 12850.5 & 89.9 \\
St 3 & 24064 & 96.5 & 6900 & 91.3 & 6704 & 71.4 & 4534 & 93.7 & 10550.5 & 90.3 \\
St 4 & 9446 & 63.5 & 8835 & 92.4 & 360 & 51.1 & 2714 & 85.3 & 5338.8 & 75.4 \\
St 5 & 22396 & 92.5 & 5934 & 49.8 & 2504 & 41.6 & -- & -- & 10278.0 & 73.2 \\
\hline
\end{tabular}

\section{The spatial and temporal distribution of Bacillariophyceae:}

Bacillariophyceae ranked the second position of dominance with an average percentage abundance of $8 \%$. Diatoms showed a higher development at stations 1,2 , and 4 with a small abundance at stations 3 and 5 (Table 3). Temporally, the results revealed a pronounce diatoms highest percentage abundance in autumn and winter. The highest average abundance of 1107 cells x $10^{5} 1^{-1}$ was recorded in autumn. The 
highest diatoms percentage abundance of $26.1 \%$ was recorded at station No. 2 during summer whereas the least of $0.1 \%$ was found at station 2 during spring.

Table 3: Bacillariophyceae distribution in the area of study (No of Cells x $10^{5} 1^{-1}$ )

\begin{tabular}{lllllllllll}
\hline & \multicolumn{2}{c}{ Spring } & \multicolumn{2}{c}{ Summer } & \multicolumn{2}{c}{ Winter } & \multicolumn{2}{c}{ Autumn } & \multicolumn{2}{c}{ Average } \\
& Abund. & $\%$ & Abund. & $\%$ & Abund. & $\%$ & Abund. & $\%$ & Abund. & $\%$ \\
\hline St 1 & 58 & 0.5 & 272 & 2.9 & 1550 & 26.0 & 1348 & 23.4 & 807.0 & 9.6 \\
St 2 & 18 & 0.1 & 298 & 26.1 & 1790 & 19.0 & 2748 & 9.6 & 1213.5 & 8.5 \\
St 3 & 292 & 1.2 & 518 & 6.9 & 200 & 2.1 & 306 & 6.3 & 329.0 & 2.8 \\
St 4 & 3838 & 25.8 & 420 & 4.4 & 4 & 0.6 & 26 & 0.8 & 1072.0 & 15.1 \\
St 5 & 1676 & 6.9 & 776 & 6.5 & 286 & 4.8 & -- & -- & 912.7 & 6.5 \\
\hline
\end{tabular}

\section{The spatial and temporal distribution of Cyanophyceae:}

Cyanophyceae ranked the third position of dominance with an average percentage abundance of $6 \%$. Cyanophyceae showed a higher development at station No. 5 with a marginal abundance at the other stations (Table 4). Temporally, the results revealed a pronounce Cyanophyceae highest percentage abundance in autumn and winter. The highest average abundance of 1181 cells $\times 10^{5} 1^{-1}$ was recorded in summer. The highest abundance of 5185 cells $\times 10^{5} \mathrm{l}^{-1}$ was recorded at station No. 5 in summer. The highest Cyanophyceae percentage abundance of 53.5\% was recorded at station No. 5 during winter whereas Cyanophyceae was not recorded station 3 during autumn.

Table 4: Cyanophyceae distribution in the area of study (No. of cells $\times 10^{5} \mathrm{I}^{-1}$ )

\begin{tabular}{lcccccccccc}
\hline & \multicolumn{2}{c}{ Spring } & \multicolumn{2}{c}{ Summer } & \multicolumn{2}{c}{ Winter } & \multicolumn{2}{c}{ Autumn } & \multicolumn{2}{c}{ Average } \\
& Abund. & $\%$ & Abund. & $\%$ & Abund. & $\%$ & Abund. & $\%$ & Abund. & $\%$ \\
\hline St 1 & 114 & 0.9 & 112 & 1.2 & 36 & 0.6 & 884 & 15.4 & 286.5 & 3.4 \\
St 2 & 364 & 2.0 & 170 & 14.9 & 6 & 0.1 & 100 & 0.3 & 160.0 & 1.1 \\
St 3 & 80 & 0.3 & 138 & 1.8 & 22 & 0.2 & 0 & 0.0 & 60.0 & 0.5 \\
St 4 & 104 & 0.7 & 300 & 3.1 & 336 & 47.7 & 442 & 13.9 & 295.5 & 4.2 \\
St 5 & 128 & 0.5 & 5185 & 43.5 & 3220 & 53.5 & -- & -- & 2844.3 & 20.3 \\
\hline
\end{tabular}

\section{The spatial and temporal distribution of Prasinophyceae:}

Although Prasinophyceae ranked the fourth position of dominance with an average percentage abundance of $2 \%$, this group was often absent in most cases except in spring and winter when it reached to its highest abundance of 2464 cells $\mathrm{x}$ $10^{5} 1^{-1}$ at station No. 3. It is worth to mention that, although the other groups (Euglenophyceae and Cryptophyceae) had a considerable number of species, they were scarcely and sporadic present in the phytoplankton communities.

\section{Phytoplankton species composition:}

The total number of taxa per site showed no obvious pattern of variation. Both the highest and lowest number of taxa was recorded at station No. 4, where the total number of taxa ranged from 51 to 17 taxa in summer and winter, respectively. The total number of taxa per month was highest during spring (177 taxa) whereas the lowest number of taxa (113) was recorded in autumn. The three dominant classes were dominated by single celled, Chlorella spp., especially Chlorella miniata (chlorophytes), Cyclotella meneghiniana and Nitzschia frustulum var. perpusilla (diatoms), Lyngbya limnetica and Chroococcus spp. (cyanoprokaryotes). Other chlorophytes, Kirchneriella spp., Crucigenia spp. and Scenedesmus spp. showed a noticeable development and shared the former taxa. Beside The dominance of $C$. meneghiniana, the pinnate diatom Nitzschia closterium was also developed throughout the lake. 


\section{DISCUSSION}

Differences in Lake Manzala cannot be explained by trophic state alone without considering other abiotic and biotic interactions. For example grazing by herbivores and competition for resources are likely to be important. There were significant qualitative and quantitative changes of zooplankton populations since 1979 till 2007 (Anonymous, 2008) where effects on phytoplankton species composition are probable. Moreover, zooplankton was heavily grazed by planktivorous fish (mainly tilapias) which may influence phytoplankton composition through 'top-down' control. Increased emergent and decline of submerged macrophytes, may also affect the phytoplankton populations.

\section{Trophic development and phytoplankton response:}

Compared with data obtained in late 1970s by (Maclaren, 1981) a trend for an increase in the proportion of small-sized species was very obvious afterward especially in 2000-2007. There was also a considerable increase in the number of individuals (or cells) of the dominant species since the 1970s. Similar results have been obtained in different studies and the authors of those studies interpreted such increases as a sign of eutrophication (Reynolds, 1984 and Korneva and Mineeva, 1996). It is generally agreed that, under the same ecological conditions, the higher the total standing crop and the number of individuals of the dominant species, the higher the trophic status (Round, 1981 and Reynolds, 1984). In addition, paleolimnological studies in Florida lakes have also shown that cyanobacterial and pico-chlorophytes proliferation increased recently and abruptly in response to eutrophication (RiedingerWhitmore et al., 2005). Both biomass, chlorophytes and cyanobacteria flourishing accompanied the increase in loadings of inorganic N, and total $\mathrm{P}$ (Johansson and Lewis, 1992) and were attributed to progressively increase in discharging of sewage and agricultural effluent.

Cyanoprokaryotes developed in 1979 with two large filamentous, Anabaena and Spirulina. These two genera decreased in time but occasionally appeared with clear dominance of coccoid, small size and non-heterocystous forms which flourished during the peak of eutrophication. Jeppesen et al. (2005) also report a reduction in heterocystous cyanobacteria during eutrophication of lakes in Denmark, in contrast to non-heterocystous forms which initially increased their densities during eutrophication. This may reflect the greater affinity of heterocystous cyanoprokaryotes to phosphorus, as suggested by (Jensen et al., 1994). These observations support the suggestion that during eutrophication, non-heterocystous species may become an increasing proportion of the cyanoprokaryotes of lakes as reported by (Jeppesen, et al., 2002). This shift in cyanoprokaryotes composition may ascribe to: firstly, increasing turbidity and delaying light penetration which sustain heterocystous forms with energy needed to fix atmospheric nitrogen and, secondly, enhancement of both organic and inorganic nitrogen which exhausted easily by small coccoid forms (Dokulil and Padisak, 1994). Chlorophyceae, especially Chlorella spp., Scenedesmus and Crucigenia spp. apparently responded best to increased phosphorus levels. Their growth in turbulent, nutrient rich waters is in accordance with reported growth (Sommer, 1991). Increasing chlorophytes over the cynaoprokaryotes in 2007 might be attributed to lower growth rates of cynaoprokaryotes compared to chlorophytes (Riedinger-Whitmore, 2005). 


\section{REFERENCES}

Abdel-Baky, T. E., Hasan, S. H. and Shallof, K. A. H. (1991). Growth of Cichild species in Lake Manzala, Egypt. Bull. Fac. Sci., Mansoura Univ., 18: 442-453.

Anonymous (2008). Ecology and Fisheries of Lake Manzala. Nat. Inst. of Ocean. Fish. Final Rep. 108 pp.

Arvola, L., Salonen, K. and Rask, M. (1999). Food webs of humic waters. Trophic interactions. In: J. Keskitalo, and P. Eloranta, P. (eds.) Limnology of humic waters. Backhuys Publishers, Leiden. The Netherlands. p. 265-276.

Billina, D., Conde, L., Aubriot, L. and Perez, M.C. (2005). Influence of hydrology on phytoplankton species composition and life strategies in a subtropical coastal lagoon periodically connected with the Atlantic Ocean. Estuaries, 28 (6): 884895.

Brettum, P. (1989). Alger som indikator på vannkvalitet i norske innsjøer. Planteplankton. Norwegian institute for water research (NIVA) report nr.2344. O-86116. $111 \mathrm{pp}$.

Dillard, G. E. (1989, 1990, and 1991). Freshwater Algae of the Southeastern, United States, By J. Krammer, Berlin, Stuttgart. (Italia.), Helsinki. 278 pp.

Dokulil, M.T. and Padisak, J. (1994). Long-term compositional response of phytoplankton in a shallow, turbid environment, Neusiedlersee (Austria/Hungary). Hydrobiol., 275/276: 125-137.

El-Sherif, Z.M. and Gharib, S.M. (2001). Spatial and temporal patterns of Ocean. and Fish., 27: 217-239.

European Union. (2000). Directive 2000/60/ECof the European Parliament and of the Council establishing a framework for the Community action in the field of water policy, Legislative Acts and other instruments. ENV221 CODEC 513.

Fayed, D.B. (2004). Aspects of Manzalah Lake Pollution on Mugil Species. M. Sc. Thesis, Girls' College, Ain Shams University.

Jensen J.P., Jeppesen, E., Olrik, K. and Kristensen, P. (1994). Impact of nutrients and physical factors on the shift from cyanobacterial to chlorophyte dominance in shallow Danish lakes. Can. J. of Fish. and Aquatic Sci., 51: 1692-1699.

Jeppesen, E., Jensen, J.P. and Søndergaard, M. (2002). Response of phytoplankton, zooplankton and fish to re-oligotrophication: an 11 year study of 23 Danish Lakes. Aquatic Ecosystem Health and Manage., 5: 31- 43.

Jeppesen E., Jensen, J.P., Søndergaard, M. and Lauridsen, T.L. (2005). Response of fish and plankton to nutrient loading reduction in eight shallow Danish lakes with special emphasis on seasonal dynamics. Freshwater Biolo., 50: 1365-1413.

Johansson, J.O. and Lewis, R.R. (1992). Recent improvements in water quality and biological indicators in Hillsborough Bay, a highly impacted subdivision of Tampa Bay, Florida, USA. Sci. Total Environ., 1199-1215 Suppl.

Khalil, M.T. (1990). Plankton and primary productivity of Lake Manzala. Egypt. Hydrobiol., 196 (3): 201-207.

Korneva, L.G., and Mineeva, N.M. (1996). Phytoplankton composition and pigment concentrations as indicators of water quality in the Rybinsk reservoir. Hydrobiol., 322: 255-259.

Krammer, K. and Lange-Bertalot, H. (1986). Bacillariophyceae. Teil: Naviculaceae. Susswasserflora von Mitteleuropa, 2/1: 1-876. Gustav Fisher Verlag, Stuttgart, Germany.

Maclaren (Engineers, Planners and Scientists) (1981). Lake Manzalah study. EGY/76/001-07. Draft Report to Arab Republic of Egypt. Ministry of 
Development and New communities and UNDP Scientists, Inc. Toronto, Canada, 12 Vols.

Reynolds, C.S. (1984). The ecology of freshwater phytoplankton. Cambridge Univ. Press, Cambridge, New York, New Rochelle, Melbourne, Sydney, 384 pp.

Riedinger-Whitmore, M.A., Whitmore, T.J., Smoak, J.M., Brenner, M., Moore, A., Curtis, J. and Schelske, C.L. (2005). Cyanobacterial proliferation is a recent response to eutrophication in many Florida lakes: a paleolimnological assessment. Lake Reser. Manage., 21 (4): 423-435.

Rosen, G. (1981). Phytoplankton indicators and their relation to certain chemical and physical factors. Limnol., 13:263-290.

Round, F.E. (1981). The Ecology of Algae. Cambridge University Press, Cambridge.

Sobhy, H.E. (2007). Distributions of phytoplankton and epipelic microalgal communities of Lake Manzala. Girls College, Ain-Shams University, 267pp.

Sommer, U. (1991). A comparison of Droop and Monod models of nutrient limited growth applied to natural populations of phytoplankton. Functional Ecol., 5: 535-544.

Starmach, K. (1968). Flora Slodkonda Polaki Toms. 594 pp.

Tikkanen, T. (1986). Kasviplanktonopas. Suomen Luonnonsuojelun Tuki Oy.

Utermohl, H. (1958). Zür Vervollkommung der quantitativen Phytoplanktonmethodik. Internationale Vereinigung für Theoretische and Angewandte Limnologie, 9: 1-38.

Willén E. (2000). Phytoplankton in Water Quality Assessment - An Indicator Concept. In: Heinonen P, Ziglio G, Van Der Beken A (eds) Hydrological and Limonological Aspects of Lake Monitoring. John Wiley\& Sons Ltd, New York

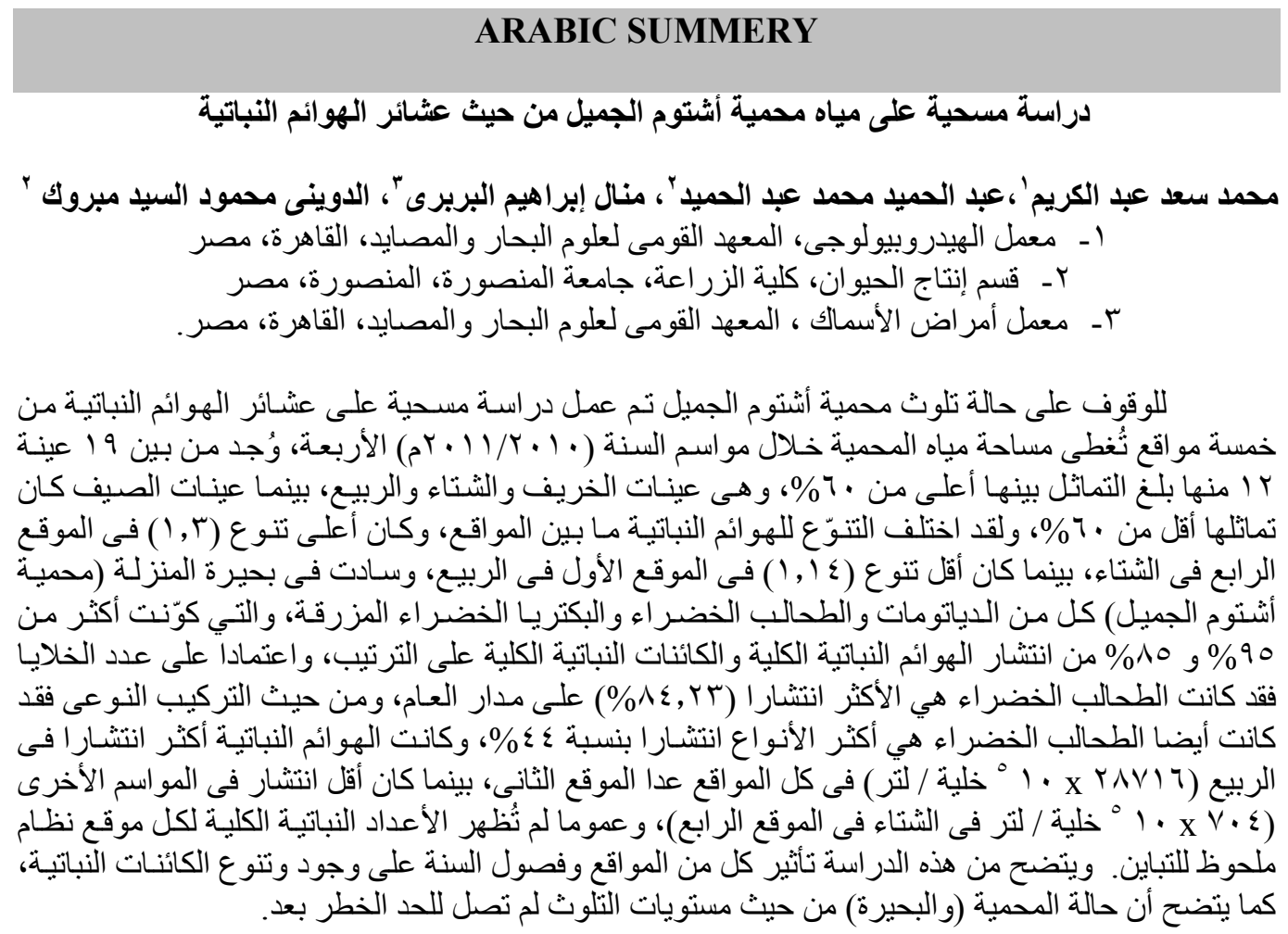

